CAHIER DE RECHERCHE \#1109E

Département de science économique

Faculté des sciences sociales

Université d'Ottawa
WORKING PAPER \#1109E

Department of Economics

Faculty of Social Sciences

University of Ottawa

\title{
Quality of Work Experience and Economic Development-Estimates using Canadian Immigrant Data
}

\author{
Serge Coulombe ${ }^{\dagger}$, Gilles Grenier ${ }^{\ddagger}$ and Serge Nadeau ${ }^{\S}$
}

December 2011

\footnotetext{
${ }^{*}$ We benefited from comments on earlier versions of the paper by Charles Beach and participants at seminars given at the 45th Conference of the Canadian Economic Association in Ottawa, the University of Bari (Italy), Université Laval, Dalhousie University, and the University of Ottawa.

${ }^{\dagger}$ Department of Economics and Research Group on the Economics of Immigration, University of Ottawa, 55 Laurier E., Ottawa, Ontario, Canada, K1N 6N5; Email: serge.coulombe@uottawa.ca.

₹ Department of Economics and Research Group on the Economics of Immigration, University of Ottawa, 55 Laurier E., Ottawa, Ontario, Canada, K1N 6N5.

$\S$ Department of Economics and Research Group on the Economics of Immigration, University of Ottawa, 55 Laurier E., Ottawa, Ontario, Canada, K1N 6N5.
} 


\begin{abstract}
There is increasing evidence in the economic development literature that the quality of schooling considerably varies across countries that are at different stages in their economic development. However, an issue that has been overlooked is the role of the quality of work experience in explaining differences in economic development. This paper uses Canadian census data on immigrant earnings to show that per capita GDP in the country of origin can be used as a quality indicator for both education and work experience. Coefficients estimated from immigrant earnings regressions are then used to estimate the effects of difference in human capital quality on development gaps between rich and poor countries. The analysis shows that while differences in the quality of schooling account for substantial differences in living standards across countries, differences in the quality of work experience can account for even more. Policywise, our results suggest that the immediate effects of improving the quality and the quantity of schooling in less-developed countries might be rather limited if labour-market institutions and ways of doing things are not changed at the same time to improve the quality of work experience.
\end{abstract}

Key words: Quality of human capital, work experience, immigrant earnings, quality of schooling, economic development.

JEL Classification: O15, J61, J24, 047, 057.

\title{
Résumé
}

La littérature sur le développement économique reconnait de plus en plus que la qualité de l'éducation varie considérablement d'un pays à l'autre selon le stade de développement. Cependant, une question qui a été ignorée jusqu'à maintenant est la contribution de la qualité de l'expérience de travail à l'explication des écarts de niveaux de vie entre les pays. L'analyse présentée dans ce document utilise des données canadiennes de recensement sur les salaires des immigrants pour montrer que le PIB par habitant du pays d'origine peut être utilisé comme indicateur de qualité pour l'éducation et l'expérience de travail acquises dans ce pays. Les coefficients estimés à partir d'équations de régression des salaires des immigrants sont ainsi utilisés pour mesurer les effets de différences de qualité de capital humain sur les écarts de niveaux de vie entre les pays riches et les pays pauvres. Les résultats montrent que quoique la qualité de l'éducation soit un déterminant majeur des écarts de niveaux de vie, la qualité de l'expérience de travail est encore plus importante du point de vue quantitatif. En ce qui concerne les politiques de développement économique, les résultats de notre analyse donnent à penser que les bénéfices à court terme d'augmenter la qualité et la quantité de scolarité dans les pays pauvres sont plutôt faibles si les institutions et les façons de faire sur les marchés du travail ne sont pas en même temps changées pour améliorer la qualité de l'expérience de travail.

Mots clés: Qualité du capital humain, expérience de travail, salaires des immigrants, qualité de l'éducation, développement économique.

Classification JEL: O15, J61, J24, 047, 057. 


\section{Introduction}

It is now generally recognized in the economic growth literature that differences in human capital are an important determinant of disparities in economic development across countries (see, for example, the seminal contribution by Mankiw, Romer and Weil, 1992). In growth accounting empirical studies, those differences are typically defined in terms of gaps in input-based education measures such as school enrolment rates (Mankiw, Romer and Weil, 1992) and years of schooling (Islam, 1995). Indeed, with the development of large cross-country datasets (Barro and Lee, 1993, 2001; de la Fuente and Doménech, 2006), the average number of years of schooling has become the benchmark variable to measure cross-country differences in human capital.

While the use of input-based measures of human capital such as years of schooling and years of work experience may be appropriate in Mincerian analyses of labour earnings of individuals living in the same region or country, it may not be in crosscountry growth analyses. The issue is that while it may be reasonable to assume that the process linking schooling and work experience to human capital formation is relatively homogeneous within a region or a country, it is probably unrealistic to assume that it is the same across countries at different stages of economic development. For example, as it is the case with other institutions, the quality and efficiency of the education process can vary substantially with the development level of a country. Indeed, it is now generally acknowledged that the quality of schooling significantly varies across countries depending on their level of economic development (Hanuskek and Kimko, 2000; Coulombe and Tremblay, 2009). As argued in Hanushek and Woessmann (2008), education has both a quantity (years of schooling) and a quality (skills) dimension. 
In their growth-accounting exercises, Klenow and Rodriguez-Clare (1997) and Hall and Jones (1999) recognize that the quality of schooling varies across countries. In particular, Klenow and Rodriguez-Clare (1997) link quality of schooling to a country's GDP per capita and-using Borjas' (1987) analysis—estimate a quality-of-schooling elasticity of 0.12 . Concretely, this means that the per capita GDP of a country that is twenty times poorer than the U.S. would increase by 36 percent (in relative terms) if the poorer country had the same quality of schooling as that of the U.S.

Despite the substantial amount of cross-country empirical research emphasizing differences in human capital, one potentially important piece of the puzzle that has been ignored so far is the role of the quality of work experience. There are indeed several reasons for the quality of work experience to vary across countries and affect economic development, including differences in customs and managerial styles that may foster (or hinder) innovative thinking (as in Bloom and Van Reenem, 2007, 2010) and differences in learning-by-doing (as in Arrow, 1962 and Romer, 1986).

In this paper, we use Canadian census data on immigrants' earnings to measure differences in human capital across countries of origin. First, we show how per capita GDP in an immigrant's country of origin can be used as a proxy for the quality of human capital acquired in that country. Second, we argue that when measuring differences in human capital across countries, we should also include differences in the quality of work experience. In particular, through a growth accounting exercise, we show that differences in the quality of work experience can contribute more than differences in the quality of education to the explanation of disparities in economic development. 
Our methodology builds on Klenow and Rodriguez-Clare (1997). Like them, we use the results of Mincerian regressions on immigrants' earnings to infer the impact of quality of human capital on economic development, and like them we assume that an immigrant's quality of human capital is a function of the GDP per capita in his or her country of origin. But in addition to including direct GDP effects in our earnings regressions (as in Borjas, 1987), we also include interactive terms between GDP per capita and the number of years of schooling and the number of years of work experience, which allows us to distinguish between the schooling quality effect and the work experience quality effect.

Of course, differences in GDP per capita across countries can be imputed to many other factors beside quality of human capital, including the quality of institutions, the degrees of corruption and rules of law enforcements, the quantity of physical and human capital, the geographic location, and the degree of openness. However, when an immigrant moves from a poor to a rich country, all those other factors are left behind and the immigrant brings only his or her human capital. Consequently, we argue that GDP per capita used in interaction with years of schooling and years of work experience can be used as a country specific indicator of human capital quality.

The results of earnings regressions on Canadian immigrants are then used to estimate the contribution of differences in quality of human capital on differences in economic development between Canada and those immigrants' countries of origin. One finding is that differences in quality of human capital indeed play an important role in explaining differences in economic development. For example, we estimate that the GDP per capita of a country that is 20 times poorer than Canada (e.g., Uganda) would increase 
by between 37.0 and 45.9 percent if the poorer country had the same human capital quality as that of Canada. Arguably our most important finding, however, is that differences in the quality of work experience play an even bigger role than differences in the quality of schooling in explaining differences in economic development. As a point of fact, we find that for a country like Uganda, the impact of the quality of work experience on economic development is about four times larger than that of the quality of schooling.

The rest of this paper is organized as follows. Section 2 presents the analytical framework. Section 3 describes the data and provides some descriptive statistics. Section 4 presents the empirical results of Mincerian regressions on immigrant earnings. Those results are translated into comparative development accounting measures in Section 5. Section 6 concludes.

\section{The analytical framework}

As in Klenow and Rodriguez-Clare (1997) and Hall and Jones (1999), assume that output $Y$ in country $j$ is produced according to

$$
Y_{j}=K_{j}^{\alpha}\left(A_{j} H_{j}\right)^{1-\alpha},
$$

where $K_{j}$ denotes the stock of physical capital, $H_{j}$ is the amount of skill-adjusted labour used in production and $A_{j}$ captures a labour-augmenting technology. In addition, assume that there are $L_{j}$ (homogenous) workers in country $j$ who are endowed with $s_{j}$ years of schooling and $x_{j}$ years of work experience on average, and that the quality of schooling and of work experience varies across countries. More specifically, assume that 


$$
H_{j}=e^{\phi\left(s_{j}, x_{j}, q_{j}\right)} L_{j}
$$

Where $q_{j}$ is a human capital quality index for country $j$ and $\phi\left(s_{j}, x_{j}, q_{j}\right)$ reflects the efficiency of $s_{j}$ years of schooling and $x_{j}$ years of work experience. For our purposes, we assume that all schooling and all work experience have been acquired in country $j$. We will refer to $\phi$ as the human capital generating function. Note that the derivatives $\phi_{s}, \phi_{x}$ and $\phi_{q}$ respectively correspond to the returns to schooling, work experience and human capital quality in a Mincerian regression wage equation framework (Mincer, 1974).

Given (1) and (2), output per worker, $y \equiv Y / L$, can be expressed as

$$
y_{j}=A_{j}\left(\frac{K_{j}}{Y_{j}}\right)^{\alpha /(1-\alpha)} e^{\phi\left(s_{j}, x_{j}, q_{j}\right)},
$$

and the percentage difference between output per worker in country $j$ and output per worker in country $k, \Delta y(j, k) \equiv \ln y_{j}-\ln y_{k}$, can be decomposed into differences in technology, physical capital intensity (as a ratio to GDP) and human capital quantity and quality:

$$
\Delta y(j, k)=\ln \left(A_{j} / A_{k}\right)+\{\alpha /(1-\alpha)\}\left\{\ln \left(K_{j} / Y_{j}\right)-\ln \left(K_{k} / Y_{k}\right)\right\}+\phi\left(s_{j}, x_{j}, q_{j}\right)-\phi\left(s_{k}, x_{k}, q_{k}\right) .
$$

Thus, the share of the percentage difference between output per worker in country $j$ and output per worker in country $k$ that is due to the difference in human capital quality can be approximated by

$$
\Delta y(j, k)_{q} \approx \phi_{q}\left(q_{j}-q_{k}\right) .
$$


Note also that if two countries have identical technologies, identical capital/output ratios and workers who are endowed with the same level of schooling and work experience, then

$$
\ln y_{j}-\ln y_{k}=\phi_{q}\left(q_{j}-q_{k}\right) .
$$

In other words, under such circumstances, the percentage difference between the two countries' output per worker is proportional to the difference in the quality of human capital.

\subsection{Using immigrant data to estimate the impact of human capital quality on output per worker}

According to (4), the share of the percentage difference between output per worker in two countries that is due to the difference in human capital quality is simply the product of $\phi_{q}$ and the difference in the human capital quality indices. Thus, given some human capital quality index $q$, one could specify a functional form for $\phi$ and obtain $\phi_{q}$ by estimating equation (3) by least-squares regression using a cross-section of countries. Another-and perhaps more convenient and statistically more reliable-approach is to estimate $\phi_{q}$ by comparing the wages of immigrant workers from different countries in the same competitive labour market. Given that in such a market, workers have access to the same capital/output ratio, the same production function, and the same institutional framework, we should expect that immigrants with exactly the same human capital characteristics should earn the same wage. However, if we observe that the wages of immigrants endowed with the same level of schooling and work experience vary systematically with their country of origin, then this probably reflects differences in the 
quality of schooling and work experience they acquired in their country of origin. Operationally, this means using results from Mincerian regressions of immigrants' wages on schooling, experience and a human capital quality index to estimate $\phi_{q}$ (in the spirit of Klenow and Rodriguez-Clare, 1997 and Hanushek and Kimko, 2000).

\subsection{Some empirical specifications for the human capital generating function}

In this section, we look at different specifications for the human capital generating function that have been used in the literature.

\section{Indirect measure of human capital quality}

When using the work of Borjas (1987), Klenow and Rodriguez-Clare (1997) implicitly specify $\phi$ as a linear function of (only) schooling and measure the quality of schooling by the natural logarithm of real GDP per capita (denoted by just GDPc henceforth), that is

$$
\phi\left(s_{j}, x_{j}, q_{j}\right)=\alpha_{1} q_{j}+\alpha_{2} s_{j}
$$

where $\alpha$ is a parameter vector and

$$
q_{j} \equiv \ln G D P c_{j}
$$

As a result, they estimate the share of the percentage difference in output per worker between two countries that is due to the difference in the quality of schooling as

$$
\Delta y(j, k)_{q}=\alpha_{1}\left(\ln G D P c_{j}-\ln G D P c_{k}\right),
$$

where the coefficient $\alpha_{1}$ comes from Borjas' estimation of a Mincerian regression equation of the form

$$
w_{i}=\alpha_{1} \ln G D P_{i} f+\alpha_{2} s_{i}+\beta_{1} x_{i}+\beta_{2} x_{1}^{2}+z_{i j} \gamma+\varepsilon_{i}
$$


on U.S. immigrant data. In Equation (8), $w_{i}$ denotes the earnings of an immigrant $i ; x$ denotes total work experience (that is, work experience in the U.S. plus work experience in the immigrant's country of origin); $z_{i j}$ denotes a vector of determinants of human capital other than years of schooling and years of work experience that might vary across individuals or country of origin; and $\varepsilon_{i}$ denotes an error term. While in a cross-country growth measurement framework, GDP per capita is an endogenous variable determined by, among other things, human capital endowments and quality, in an immigrant wage determination econometric framework, an immigrant's country of origin GDP per capita is a strictly exogenous variable. An issue with this approach though is that GDP per capita is an indirect measure of quality that may reflect other factors such as an immigrant self-selection effect (as argued in Borjas, 1987).

\section{Direct measure of human capital quality}

Another formulation for the human capital generating function that has been used in the growth literature is that of Hanushek and Kimko (2000), Coulombe et al. (2004), and Coulombe and Tremblay (2006). In these papers, the quality index is constructed using average country scores on cognitive tests conducted by the International Association for the Evaluation of Educational Achievement and the International Assessment of Educational Progress. While cognitive tests provide more direct measures of human capital quality than GDP per capita, they have the disadvantage of being available for far fewer countries and for much shorter periods of time. For example, test scores from the International Adult Literacy and Skills Survey are available for only 27 countries while 
data on GDP per capita are available for 188 countries and as many as 55 years in Heston, Summers, and Aten (2009).

Human capital generating functions in the literature on the labour market integration of immigrants

Researchers in the labour market integration of immigrants literature often estimate human capital generating functions that are more general than (5). These studies generally assume that not only the quality of schooling, but also the quality of work experience acquired in foreign countries is different from that acquired domestically (such as in Canada or the U.S. for example). Furthermore, they assume that the effect of quality of schooling is not constant across years of schooling - the intuition being that in particular, one should expect the quality effect to be greater the more schooling an individual is endowed with. ${ }^{1}$ Thus, for example, with Canadian data on immigrants, Sweetman (2004) uses the average score on cognitive tests conducted in an immigrant's country of origin as an indicator of the quality of schooling (that is as $q_{i j}$ ) and estimate an immigrant wage regression equation of the form

$$
\ln w_{i}=\alpha_{1} q_{i j}+\alpha_{2} s_{i}+\alpha_{3} s_{i} q_{i j}+\beta_{1} x_{f i}+\beta_{2} x_{f i}^{2}+\beta_{3} x_{d i}+\beta_{4} x_{d i}^{2}+\beta_{5} x_{f i} x_{d i}+z_{i j} \gamma+\varepsilon_{i}
$$

where $x_{f}$ denotes years of work experience in the immigrant's country of origin and $x_{d}$ denotes years of work experience in the domestic market (Canada in that case).

\subsection{Proposed specification}

Our specification of the human capital generating function bridges the growth literature and the immigrant earnings literature in that regard. In particular, drawing from the

\footnotetext{
${ }^{1}$ Another way of saying this is that if there is a difference in the quality of schooling between two countries, then one should expect the difference to be larger (in terms of wages differences) at the university graduate level than at the elementary level, for example.
} 
immigrant earnings literature, we build on the growth literature by assuming that not only the quality of schooling varies across countries, but also the quality of work experience, and that the effect of quality varies with the level of schooling and work experience. Specifically, we model $\phi$ as

$$
\phi\left(s_{j}, x_{j}, q_{j}\right)=\alpha_{1} q_{j}+\alpha_{2} s_{j}+\alpha_{3} s_{j} q_{j}+\beta_{1} x_{j}+\beta_{2} x_{j}^{2}+\beta_{3} x_{j} q_{j}+\beta_{4} x_{j}^{2} q_{j}+\beta_{5} x_{j}^{2} q_{j}^{2} .
$$

While the assumption that the quality of work experience varies across countries is (to our knowledge) completely novel in the economic growth literature, it is highly intuitive. Indeed, just as the quality of work experience enhances human capital and, by extension, earnings at the individual's level, one should expect that it would do the same at the aggregate level.

\section{Estimation considerations}

The coefficients in (10) can be estimated using immigrant wage data as follows. If we assume that an immigrant's years of work experience that have not been acquired domestically (for example, in Canada) have been acquired in his or her country of origin and if we restrict the regression sample to only immigrants who have acquired their highest diploma in their country of origin, then the coefficients in (10) can be estimated through an earnings regression of the form

$$
\begin{aligned}
\ln w_{i}= & \alpha_{1} q_{i j}+\alpha_{2} s_{i}+\alpha_{3} s_{i} q_{i j}+\beta_{1} x_{f i}+\beta_{2} x_{f i}^{2}+\beta_{3} x_{f i} q_{i j}+\beta_{4} x_{f i}^{2} q_{i j}+\beta_{5} x_{f i}^{2} q_{i j}^{2} \\
& +\beta_{6} x_{d i}+\beta_{7} x_{d i}^{2}+\beta_{8} x_{f i} x_{d i}+\beta_{9} x_{d i} x_{f i} q_{i j}+z_{i j} \gamma+\varepsilon_{i} .
\end{aligned}
$$

That is, under such assumptions, the returns to an immigrant's years of schooling and years of foreign experience in the domestic market correspond to the returns to schooling 
and work experience acquired in that immigrant's country of origin. ${ }^{2}$ Three observations are in order.

First, note that with regards to human capital quality, the formulation in Borjas (1987)/Klenow and Rodriguez-Clare (1997) and Hanushek and Kimko (2000), which is equation (8), is a special case of (11) when $\alpha_{3}=\beta_{3}=\beta_{4}=\beta_{5}=\beta_{8}=\beta_{9}=0 ; \beta_{1}=\beta_{6}$; and $\beta_{2}=\beta_{7}$

Second, note also that if the representative worker in country $j$ is endowed with a level of schooling $s_{j}$ and a level of work experience $x_{j}$, then the portion of the percentage difference between output per worker in country $j$ and that in country $k$ explained by the difference in human capital quality from the point of view of country $j$ (that is, equation (4) evaluated at $s_{j}$ and $x_{j}$ ) is

$$
\Delta y(j, k)_{q}=\left(\alpha_{1}+\alpha_{3} s_{j}+\beta_{3} x_{j}+\beta_{4} x_{j}^{2}\right)\left(q_{j}-q_{k}\right)+\beta_{5} x_{j}^{2}\left(q_{j}^{2}-q_{k}^{2}\right)
$$

which can be decomposed into three components:

a Direct quality effect: $\alpha_{1}\left(q_{j}-q_{k}\right)$,

a Schooling-quality effect: $\alpha_{3} s_{j}\left(q_{j}-q_{k}\right)$,

and

a Work-experience-quality effect: $\left(\beta_{3} x_{j}+\beta_{4} x_{j}^{2}\right)\left(q_{j}-q_{k}\right)+\beta_{5} x_{j}^{2}\left(q_{j}^{2}-q_{k}^{2}\right)$.

Finally, in the same vein as Borjas (1987)/Klenow and Rodriguez-Clare (1997), in our regressions, we will use GDP per capita as an indicator of an immigrant country of

\footnotetext{
${ }^{2}$ The cross-product terms between domestic experience $\left(x_{d}\right)$, country of origin experience $\left(x_{f}\right)$ and quality of human capital $(q)$ is simply the result of the usual Mincerian assumption that the contribution of experience to wages is a quadratic function of total experience measured in efficiency units, which is $x_{f}+x_{f} q+x_{d}$ in our framework.
} 
origin's human capital quality. In particular, we will use the following specification for the human capital quality index:

$$
q_{j}=\ln \left(\frac{G D P c_{j}}{G D P c_{\text {Canada }}}\right) .
$$

The advantages of this specification are that being a logarithm, it can easily be interpreted and that it is comparable to the human capital quality index used in Borjas (1987) and Klenow and Rodriguez-Clare (1997).

A point of caution though concerns the interpretation of the coefficient $\alpha_{1}$ and of the Direct-quality effect (as defined by equation (12a)) in the presence of interactive effects (as defined by equations $12 \mathrm{~b}$ and 12c). Because $\alpha_{1}$ measures the human capital quality effect when Years of schooling and Years of work experience are zero, it may reflect the quality effect of unobservable skills of immigrants (e.g., motivation, ambition). If our estimate of $\alpha_{1}$ turns out positive, then this could suggest that immigrants from poorer countries are not the most able and the most ambitious persons in their country of origin (as postulated by Borjas, 1987) or that they are willing to settle for lower wages than immigrants from richer countries simply because of their poorer labour market alternatives. On the other hand, if our estimate of $\alpha_{1}$ turns out negative, then it could suggest that immigrants from poorer countries have better unobservable skills than immigrants from richer countries. One way or the other though, our estimate of $\alpha_{1}$ would reflect immigrant self-selection effects, which means that the value of this coefficient should not be used to infer about the quality of human capital of residents in foreign countries to explain differences in economic development. Nevertheless, for the 
sake of completeness, we prefer to at least initially allow for these effects in our regressions and let the data speak for itself.

\subsection{GDP per capita as an indicator of human capital quality}

In this section, we expand on the rationale for using GDP per capita as an indicator of human capital quality. As mentioned earlier, a great practical advantage of using GDP per capita instead of other possible quality indicators (such as results of cognitive tests) is that data on GDP per capita are generally comparable across countries and available for most countries in the world over long periods of time. However, there are also several other (more) conceptual reasons for using GDP per capita as an indicator of human capital quality.

An obvious reason why one should expect GDP per capita to be a good indicator of human capital quality is that countries with high GDP per capita generally have more monies to spend on schools, teachers and the like. As a result, one should expect that the quality of education in a country would increase with that country's GDP per capita.

Another reason for using GDP per capita as an indicator of human capital quality is the link between the quality of work experience and the notion of learning by doing. Across countries, differences in customs, in employer-employee relationships/labour relations and differences in managerial styles may foster (or hinder) innovative thinking as in, for example, Bloom and Van Reenem (2007, and 2010). Since the seminal work of Arrow (1962) and its introduction into endogenous growth models by Romer (1986), learning-by-doing at the firm level is often assumed to be a function of the capital/labour ratio of the overall economy. In the framework of this paper, we can think of the value of the work experience of an individual in a given country to be determined by the physical 
and human capital intensity of that country. In this context, a country's GDP per capita, itself a function of the capital intensity of that country, is a straightforward proxy for its quality of work experience.

At the aggregate level, GDP per capita is determined by a variety of institutional, geographical, sociological, and political factors. However, when an individual is migrating to another country, he is bringing with him his human capital and is leaving behind most of the other determinants of his country's GDP per capita.

Finally, it is worth mentioning that since in an immigrant earnings regression, an immigrant's country of origin GDP per capita is a strictly exogenous variable, any correlation between country of origin GDP per capita and earning is an indication of causality. And, if there is any causal link, it has to run from GDP per capita to earning and not the other way around.

\section{Data and summary statistics}

Canada provides the ideal ground to test our model as it has one of the largest and most culturally diverse intake of immigrants among the world developed economies. For example, Statistics Canada estimates that in 2006, almost 20 percent of all Canadians were born abroad (Statistics Canada, 2009). Canada receives annually more than 250,000 immigrants, distributed among three major classes: economic immigrants, family reunification, and refugees. The majority (69\% in 2010) are economic immigrants, but the proportions have changed through time. In the 1980's and early 1990's, economic immigrants used to be the minority. Economic immigrants are admitted through the Point System, which gives points to candidates based on their education, age, work experience, 
language skills and other factors. Because of that particular policy, immigrants to Canada tend to be relatively highly educated, compared to immigrants to other countries, notably the United States.

The data used for our analysis come from the Statistics Canada 2006 Census Microdata Masterfile, which provides a very large sample of immigrants, with very detailed information on their countries of origin. To eliminate as many extraneous factors as possible, the sample is restricted to working age men who worked full-time full-year in 2005, who were not self-employed and who obtained their highest certificate, degree or diploma in their country of origin. Working age is defined as ages 18 to 64 , Full-time is defined as 30 hours or more a week and Full-year is defined as 49 weeks or more. The number of years of schooling is not available directly from the data and is defined on the basis of the highest certificate, degree or diploma (see Table A1 in appendix). Potential work experience is defined as Age minus Years of schooling minus 6. Data on GDP per capita come from Heston, Summers, and Aten (2009) and is adjusted for purchasing power parity. Relative GDP per capita is measured at the year of immigration (that is, at the year when landed immigrant status was first obtained in Canada). Appendix A provides further details on the variables used in our analysis.

Table 1 provides summary statistics on Canadian born and immigrant workers in our sample. It is interesting to note that despite being endowed with more years of schooling and work experience, immigrants earn on average about 10 percent less than Canadian born individuals. A number of labour economists have argued that one reason for the existence of this gap is that the human capital quality of immigrants in Canada is 
lower than that of Canadian born individuals (see, for example, Sweetman, 2004, and Bonikowska, Green and Riddell, 2008).

(Table 1 approximately here)

\section{Empirical results}

In this section, we report estimates of nested versions of the immigrant earnings equation (11), from the most restricted to the least restricted. This allows for the examination of changes in coefficient estimates following the removal of restrictions. The estimated coefficients of interest are reported in Table 2. As a point of comparison, we also include the estimated coefficients of an earnings regression on Canadian born individuals.

(Table 2 approximately here)

\subsection{Base case: No control for human capital quality}

The most restricted case of (11) is when it is assumed that from a human capital point of view, the quality of one year of schooling or work experience acquired in an immigrant's country of origin is the same as that acquired in Canada, which corresponds to equation (8) with $\alpha_{1}$ set equal to zero. The results in the column labelled Model 1 in Table 2 show that if such assumption was correct then the returns to human capital would significantly be lower for immigrants than for Canadian born individuals. For example, the Mincerian returns to years of schooling and years of work experience (evaluated at zero years of work experience) would respectively be 6.1 percent and 2.7 percent per year for immigrants compared with 8.7 percent and 5.9 percent per year for Canadian born individuals. 


\subsection{Work experience acquired in Canada vs. work experience acquired abroad}

Model 2 in Table 2 is a first step towards distinguishing between the quality of human capital acquired in Canada and that acquired in another country. This model makes a distinction between work experience acquired in Canada and work experience acquired in an immigrant's country of origin. This model corresponds to equation (11) with the restriction $\alpha_{1}=\alpha_{3}=\beta_{3}=\beta_{4}=\beta_{5}=\beta_{9}=0$. The results strongly support the notion that human capital quality varies across countries and in particular that the quality of work experience is perceived by Canadian employers to be lower if the work experience has been acquired outside Canada. Indeed, according to figures in the fourth column of Table 2, all other things equal, immigrants earn 1.9 percent more per year of work experience acquired in Canada than that acquired outside Canada (4.1 percent per year compared with 2.2 percent per year).

\subsection{Using relative GDP as a human capital quality indicator in the regression}

Model 2 is a rather crude way of modeling the effect of quality of schooling and work experience on earnings as it pre-supposes that it is the same for all countries of origin, which is clearly untenable, especially in light of results in international standardized literacy tests and is therefore not useful for estimating the impact of human capital quality on economic development along the lines discussed in Section 2. Model 3 and Model 4 are attempts to correct for that by introducing Relative GDP per capita as a human capital quality indicator. Model 3 allows for human capital quality to affect earnings only

directly (à la Borjas, 1987; Klenow and Rodriguez-Clare, 1997; and Hanushek and Kimko, 2000) while Model 4 allows for human capital quality to affect earnings both directly and indirectly through the returns to years of schooling and years of work 
experience. Specifically, Model 3 corresponds to equation (11) but with the restriction $\left(\alpha_{3}=\beta_{3}=\beta_{4}=\beta_{5}=\beta_{9}=0\right)$ while Model 4 corresponds to equation (11) without restriction.

Looking at the coefficient estimates of Model 3 in Table 2, we find that Relative GDP per capita has a highly statistically significant and economically substantial impact on an immigrant's earnings. Specifically, we find that an immigrant's earnings elasticity with respect to this variable is 0.136 . This is actually slightly larger than the value of 0.116 found in Borjas (1987) and Klenow and Rodriguez-Clare (1997) using U.S. data. It suggests, for example, that an immigrant from a country whose GDP per capita is 5 percent that of Canada earns about 40 percent less than another immigrant who comes from a country whose per-capita GDP is comparable to that of Canada, but who is similar in all other respects. ${ }^{3}$

While the results of Model 3 clearly show that Relative GDP per capita has a positive direct impact on immigrants' earnings, we are concerned that Relative GDP per capita may be capturing more than a human capital quality effect. Indeed it could be capturing the effects of a host of other factors beside quality of schooling and of work experience, such as, for example, an immigrant self-selection effect (Borjas, 1987).

The coefficient estimates of Model 4 in Table 2 provide a more convincing argument that Relative GDP per capita is an appropriate indicator of human capital quality. Indeed, we find that the effects of Relative GDP per capita on immigrants' earnings seem to be mostly operating through the Years of schooling and Years of work experience variables: the interaction effects of Relative GDP per capita are all highly

\footnotetext{
${ }^{3}$ All percentage changes in this paper are computed using natural logarithmic differences.
} 
statistically significant and of the expected signs (that is, they are positive). However, the direct impact of Relative GDP per capita is now negative (although barely statistically significant at the five percent level). This suggests that the quality of the unobserved skills (e.g., ambition, motivation) of immigrants from poorer countries nay be higher than that of immigrants from richer countries, and may reflect an immigrant positive selfselection effect, which would have nothing to do with the human capital quality of individuals who decide to stay in their countries of origin and not immigrate.

\subsection{The robustness of our results}

We perform a number of tests to evaluate the robustness of our results. The column labelled Model 5 in Table 2 reports the estimates of the coefficients of interest when we add immigrant country of origin fixed effects in the regression; the intent of this test is to check whether Relative GDP per capita effects could just be picking up country of origin effects unrelated to quality of schooling and work experience (labour market discrimination for example). ${ }^{4}$ Our results suggest that it is not the case. Indeed, while the $R^{2}$ increases significantly (from 0.237 to 0.271 ), the Relative GDP per capita effects change very little: the direct effect is only slightly less negative (although it is now statistically insignificant) while the effects through schooling and work experience barely budge and remain statistically significant. ${ }^{5}$

In light of the difficulty in interpreting in terms of human capital quality the direct Relative GDP per capita effect and the fact that it is statistically insignificant, we estimate another model where the direct Relative GDP per capita effect is excluded from

\footnotetext{
${ }^{4}$ Note that Relative GDP per capita is not perfectly collinear with country of origin fixed effects in our regression since Relative GDP per capita is measured at the time of immigration, which means that it not only varies across countries of origin but also across immigrants.

${ }^{5}$ The impact of Relative GDP per capita at the means of the variables is the same for Model 4 and Model 5 up to the second decimal for Years of schooling and up to the fifth decimal for Years of work experience.
} 
the regression but the fixed country effects are kept. The results are reported in the column labelled Model 6 in Table 2. Note that the Relative GDP per capita effects estimated through schooling and work experience under this model are very similar to those estimated under Model 5; as a point of fact, none of the estimates of the coefficients attached to the variables in $q$ in Model 6 are statistically different from those estimated under Model 5.

Finally, other variations of Model 4 in Table 2 were estimated but are not reported here. For example, we tested an alternative specification for our human capital quality index than the one specified in equation (13). The alternative specification was

$$
q_{j}=\frac{G D P c_{j}}{G D P c_{\text {Canada }}}-1
$$

We also tried relative life expectancy at birth instead of Relative GDP per capita as an indicator of quality of skills (the rationale being that life expectancy at birth is another widely available statistics related to well-being that may be measured with less error than real GDP per capita). In all these cases, the results were generally similar to those in Table 2, while their interpretation was not as intuitive.

\section{Human capital quality and economic growth}

The regressions results of equation (11) presented in Table 2 come from the analysis of earnings of individual Canadian immigrants. In this section, we return to the macroeconomic growth accounting framework outlined in Section 2 and use the coefficients estimated under our preferred model (Model 6) along with equation (12) to estimate how much of the difference in GDP per capita between rich countries (e.g., Canada, United States) and poor countries is due to differences in human capital quality. 
Ratios of GDP per capita in rich countries to GDP per capita in poor countries can be as large as 20 or even 30 to 1 . Tables $3,4,5$ and 6 present results for three typical poor economies: Uganda which is representative of many sub-Saharan economies for which Canada has a GDP per capita ratio of 20 to 1 ; India for which the ratio is 10 to 1 ; and Argentina for which Canada has a per capita GDP ratio of 2 to 1 . We also include results for the U.S. where GDP per capita is about 22 percent higher than in Canada (Heston, Summers, and Aten, 2009), which translates into a Canada-U.S. GDP per capita ratio of about 0.8 to 1 .

The figures in Table 3 show how much of the logarithmic percentage difference between a country's GDP per capita and that of Canada is due to the difference in human capital quality. Specifically, these figures correspond to equation (12) evaluated at various values of $s(4,8$, and 12 years of schooling) and $x(20,25$, and 30 years of work experience) using the coefficients estimated under Model 6 in Table 2. In a companion table, Table 4, the results from Table 3 are presented in terms of GDP ratios. They illustrate what would be the ratio between Canada's and another country's GDP per capita if human capital quality was the same, holding all other factors constant.

(Tables 3, and 4, approximately here)

The figures in tables 3 and 4 clearly demonstrate that differences in human capital quality matter a lot for explaining differences in GDP per capita between rich and poor countries. For example, if we assume that the representative worker in Uganda has four years of schooling (the average number of years of schooling in Uganda is 3.5 according to Barro and Lee, 1993) and 30 potential years of work experience, then we estimate that Uganda's GDP per capita would increase by 45.9 percent if it had the same human capital 
quality as that of Canada. Under such circumstances the ratio of Canada's GDP per capita to that of Uganda's would decrease from 20:1 to 13.7:1.

It also interesting to see that for more developed countries such as India and Argentina, differences in human capital quality also account for substantial differences in GDP per capita. For example, assuming that the representative worker in India is endowed with 8 years of schooling and 25 years of work experience, we estimate that the ratio of Canada's GDP per capita to that of India would decrease from 10:1 to 7.12:1 if India's human capital quality was the same as Canada's. In the case of Argentina, the ratio would decrease from 2:1 to $1.76: 1$ under such circumstances.

Of course the difference is much smaller for economies that are relatively similar to each other (such as Canada and the U.S.). For example, assuming that workers in both Canada and the U.S. have on average 12 years of schooling and 20 years of work experience, then Table 3 suggests that if Canada had the same human capital quality as the U.S., Canada's GDP per capita would increase by 4.6 percent. In other words, human capital quality only accounts for about 20 percent of the difference in living standards between these two countries.

It is noteworthy that we find that human capital quality has a greater impact on economic development than that reported in Klenow and Rodriguez-Clare (1997). For Uganda, for example, Klenow and Rodriguez-Clare (1997) would estimate that the difference in human capital quality with Canada would account for 36 percent of Uganda's GDP, compared to our estimate of between 37.0 and 45.9 percent (depending on the number of potential years of work experience assumed for the representative Ugandan worker). For Canada compared to the United States, our estimate of 4.6 percent 
(assuming that the representative U.S. worker has 12 years of schooling and 20 potential years of work experience) is almost twice as large as what would be obtained using Klenow and Rodriguez-Clare (1997)'s methodology.

\subsection{Decomposition of the impact of human capital quality}

Table 5 reports the decomposition of the impact of differences in human capital quality on GDP per capita into a Schooling quality effect and Work-experience quality effect-as per equations (12b) and (12c)_for selected combinations of Years of schooling and Years of work experience. ${ }^{6}$

(Table 5 approximately here)

The results are striking. In all cases, the quality of work experience plays a much bigger role in explaining differences in GDP per capita than the quality of schooling. For example, if we take the case of Uganda for 4 years of schooling and 30 years of potential work experience, the Work-experience quality effect is more than four times as large as the Schooling quality effect. In the case of India with 8 years of schooling and 25 years of work experience, the Work-experience quality effect is more than twice as large as the Schooling quality effect.

The results displayed in Tables 5 are in some respect the most revealing of this study. Up to now, to our knowledge, the economic growth literature has focus exclusively on the schooling aspect of human capital when studying the impact of human capital quality on standards of living. In this paper, we show that a country's quality of schooling is indeed an important determinant of its standards of living. However, our

\footnotetext{
${ }^{6}$ The Direct quality effect is estimated to be zero under Model 6 (our favourite model) and is therefore ignored in the decomposition.
} 
bottom line is that the quality of work experience is an even more important determinant from a quantitative point of view. This might not be surprising ex-post since we know that in poor countries, the number of years of schooling is typically small, sometimes around four years, and consequently the potential number of years of work experience is large as people often start working at early ages. Nevertheless, normalizing our estimates for the number of years of schooling and the number of years of work experience, we find that the quality impact on GDP per capita of one year of work experience is still substantial compared to that of one year of schooling-about 80 percent of the latter in fact (see Table 6).

(Table 6 approximately here)

Clearly, further research is needed to better understand the factors that determine the quality of work experience in countries at different stages in their economic development. In the basic Mincerian framework, returns to work experience are explained by the fact that workers invest in human capital on the job to become more productive later. Our results show that the return to such investment is higher if this investment is made in a rich country than if it is made in a poor country. An obvious explanation is that from an economic development point of view, on-the-job training is more valuable if it is acquired while working with sophisticated tools and within complex organizations than it is otherwise. For example, most would agree that from an economic development point of view, working with computers provides more valuable training than working with abaci.

Another possible explanation why we find that the return to work experience is higher if it is acquired in rich countries than if it is acquired in poor countries may just be 
an artefact of the data we use. The issue is that Potential work experience-which is measured as age minus Years of schooling and which we use in our regressions to approximate Years of work experience-may be a deficient indicator of work experience acquired in poorer countries because of high unemployment in these countries. If actual experience that excludes spells of unemployment were available, perhaps the returns to work experience in an immigrant's country of origin would be higher.

\section{Summary and conclusion}

In this paper, we present a methodology to analyze the effects of human capital quality on economic development. In a first step, we show how we can use GDP per capita as a cross-country proxy for the quality of schooling and work experience in Mincerian immigrant earnings regression. The approach is appealing for a number of reasons. One reason is that we should expect GDP per capita to be a good indicator of human capital quality because rich countries generally spend more monies on schools, teachers and the like, and also provide better on-the-job learning opportunities (as they are, among other things, more technologically advanced) than poor countries. Another reason is that while cognitive test scores are available for quite a limited number of countries for cross-country comparison purposes, data on GDP are available for most countries in the world and for long periods of time. Finally, whereas it would not be possible to use GDP as a proxy for the quality of schooling in a cross-country growth study because of an obvious endogeneity issue, GDP per capita is a strictly exogenous variable in an empirical analysis of immigrant earnings. What immigrants bring with them when they move to another country is their human capital-the other factors that determine GDP in the country of origin are left behind. 
In a second step, we estimate our earnings regression using data on GDP per capita from the Heston, Summers and Aten's (2009) Penn World Tables and data on Canadian immigrant earnings, human capital and other characteristics from the Statistics Canada 2006 Census Microdata Masterfile. Key to our modeling is allowing interactions between our human capital quality indicator (that is, Relative GDP per capita) and the Years of schooling and the Years of work experience variables in our immigrant earnings regressions. The fact that the regression coefficients associated with these interaction terms are much more economically and statistically significant than the Relative GDP per capita direct effect regression coefficient (as in Borjas, 1987) should convince even the most sceptic reader that GDP per capita captures something related to the quality of education and work experience.

In a third step, we translate the estimated returns to quality-adjusted schooling and quality-adjusted work experience into aggregate effects in a cross-country growth accounting framework. We find that combining the quality adjustments for both schooling and work experience leads to human capital quality adjustments that are larger than those previously found in the literature. Perhaps more importantly though, we find that, quantitatively speaking, the quality of work experience plays a much bigger role in explaining differences in economic development than the quality of schooling.

As emphasized by Hanushek and Woessmann, (2008), one of the key facts revealed by recent economic development experiences is that improvements in the quantity of education have not always yielded the expected progress in terms of economic well being. They convincingly argue that the quality of schooling should also be improved. The results of our analysis confirm their diagnostic: differences in the quality 
of schooling are substantial between rich and poor countries. However, our analysis also highlights another potential explanation for the weak impact of improving schooling on economic wellbeing in poor countries: the low quality of work experience in those countries. In fact, we estimate that quantitatively speaking, the quality of work experience has a greater impact than the quality of schooling in explaining economic development gaps. Improving schooling quantity and quality would certainly improve the stock of human capital in poor countries. However, improving the quality of work experience might achieve even more. Our results thus introduce the notion that, ideally, from a human capital point of view, an economic development process should be balanced: it should be characterized by simultaneous improvements in both schooling and labour market experience.

Finally, our results might shed new light on our understandings of the international transferability of human capital (see for example, Chiswick and Miller, 2008). The return to education and work experience of Canadian immigrants appears to be affected by the degree of economic development in their country of origin. The weak transferability of human capital (abstracting from language skills) might result from quality differences in the human capital formation process.

\section{References}

Arrow, Kenneth J. 1962. "The Economic Implications of Learning by Doing." Review of Economic Studies 29 (1):155-73.

Barro, Robert J. and Jong-Wha Lee 1993. "International Comparisons of Educational Attainment." Journal of Monetary Economics 32(3):363-394. 
Barro, Robert J. and Jong-Wha Lee 2001. "International Comparisons of Educational Attainment: Updates and Implications." Oxford Economic Papers 53(3):541563.

Bloom, Nick and John Van Reenen 2007. "Measuring and explaining management practices across firms and countries." Quarterly journal of economics 122 (4):1351-1408.

Bloom, Nick and John Van Reenen 2010. "Human resource management and productivity." in Orley Ashenfelter and David Card, eds. Handbook of labor economics. Elsevier.

Bonikowska, Aneta, David Green and W. Craig Riddell 2008. Literacy and the Labour Market: Cognitive Skills and Immigrant Earnings. Catalogue no. 89-552-M, Research Report No. 20. Ottawa: Statistics Canada.

Borjas, George J. 1987. "Self-selection and the earnings of immigrants." American Economic Review 77(4):531-553.

Chiswick, Barry R. and Paul W. Miller 2009. "The international transferability of immigrants' human capital."Economics of Education Review, 28(2):162-169.

Coulombe, Serge and Jean-François Tremblay 2006. "Literacy and Growth," B.E. Journals in Macroeconomics Vol. 6, No. 2, pp. 1-32.

Coulombe, Serge and Jean-François Tremblay 2009. "Migration and Skills Disparities across the Canadian Provinces." Regional Studies 43(1):5-18.

Coulombe, Serge, Jean-François Tremblay, and Sylvie Marchand. 2004. Literacy Scores, Human Capital and Growth across Fourteen OECD Countries. Ottawa: Statistics Canada.

De la Fuente, Angel and Rafael Domenech 2006, "Human Capital in Growth Regressions: How much Difference Does Data Quality Make?", Journal of the European Economic Association 4(1):1-36.

Hall, Robert E. and Charles I. Jones 2000. "Why do some countries produce so much more output per worker than others?" Quarterly Journal of Economics 115(1):103-116.

Hanushek, Eric A. 2003. “The Failure of Input-Based Schooling Policies.” Economic Journal 113(485):F64-F98.

Hanushek, Eric A. and Dennis D. Kimko 2000. "Schooling, Labor-Force Quality, and the Growth of Nations." American Economic Review 90(5):1184-1208. 
Hanushek, Eric A. and Luger Woessmann 2008. "The Role of Cognitive Skills in Economic Development." Journal of Economic Literature 46(3):607-668.

Heston, Alton, Robert Summers and Bettina Aten 2009, "Penn World Table Version 6.3." Center for International Comparisons of Production, Income and Prices. University of Pennsylvania.

Klenow, Peter J. and Andrés Rodriguez-Clare 1997. "The Neoclassical Revival in Growth Economics: Has It Gone Too Far?" in Ben S. Bernanke and Julio J. Rotemberg, eds. NBER macroeconomis annual 1997. Cambridge, MA: MIT Press, pp. 83-103.

Mincer, Jacob 1974. Schooling, experience and earnings. New York: National Bureau of Economics Research.

Mankiw, N. Gregory, David Romer and David N. Weil 1992. "A Contribution to the Empirics of Economic Growth." Quarterly Journal of Economics 107(2):407437.

Romer, Paul 1986. "Increasing Returns and Long-Run Growth." Journal of Political Economy 94(5):1002-1037.

Statistics Canada. 2009. Immigration in Canada: A Portrait of the Foreign-born Population, 2006 Census: Immigration: Driver of population growth. Accessed August 1, 2011 at http://www12.statcan.ca/census-recensement/2006/as-sa/97557/p2-eng.cfm.

Sweetman, Arthur 2004. Immigrant Source Country Educational Quality and Canadian Labour Market Outcomes Catalogue. No. 11F0019MIE Research Report No. 234. Ottawa: Statistics Canada.

\section{APPENDIX A}

\section{DATA DESCRIPTION}

\section{Dependent variable}

Our dependent variable is the natural logarithm of weekly earning. Weekly earning is calculated as wages and salaries reported for 2005 divided by the number of weeks worked in 2005 . 
Some restrictions were applied to eliminate very small and very large values of earnings. Observations with annual wages less than $\$ 1000$ and less than $\$ 2$ per hour in the reference week were removed. The sample was also restricted to individuals who had obtained their (post-secondary) highest certificate, diploma or degree in their country of origin according to the Location of study variable in the 2006 census. For individuals without post-secondary certificate, diploma or degree, we assumed that they had acquired their education in their country of origin except if they had immigrated to Canada before they turned 18, in which case we assumed they had completed their education in Canada (and therefore were excluded from the sample).

\section{Independent variables}

We allow earnings to vary by a fixed effect across Canada. We control for six regions: the Atlantic Provinces, Quebec, Ontario (the reference category), the Prairies, Alberta and British Columbia.

The 2006 census does not provide a value for Years of schooling. To compute this value we use the information provided on the highest certificate, degree or diploma obtained in the way described in Table A1. In the census, the variable location of study is reported only for individuals who have completed a postsecondary certificate, diploma or degree.

Potential experience is defined as Age minus Years of schooling minus 6. Foreign experience is measured as potential experience minus Years since migration, where Years since migration is calculated as 2005 minus the year the individual's year of immigration (that is, the year landed immigrant status was first granted). Domestic experience is defined as potential experience minus foreign experience. 
For language skill, we use the variable Knowledge of the official languages (as evaluated by the respondents). The categories are (1) English only (the reference), (2) French only, (3) Both English and French, and (4) None of English and French.

Table A1: Construction of Number of Years of Schooling Variable

\begin{tabular}{|l|c|}
\hline $\begin{array}{c}\text { Highest certificate, degree or } \\
\text { diploma obtained }\end{array}$ & Estimated years of schooling \\
\hline No certificate & 8 \\
\hline High school certificate & 12 \\
\hline $\begin{array}{l}\text { Trade, apprenticeship, college or } \\
\text { CEGEP certificates or diploma } \\
\text { from a program of three months } \\
\text { to less than one year }\end{array}$ & 13 \\
\hline $\begin{array}{l}\text { Trade, apprenticeship, college or } \\
\text { CEGEP certificates or diploma } \\
\text { from a program of one year to } \\
\text { two years }\end{array}$ & 14 \\
\hline $\begin{array}{l}\text { University certificate or diploma } \\
\text { below bachelor level }\end{array}$ & 15 \\
\hline University bachelor level & 16 \\
\hline $\begin{array}{l}\text { University certificate or diploma } \\
\text { above bachelor level }\end{array}$ & 17 \\
\hline Masters & 18 \\
\hline $\begin{array}{l}\text { Doctorate (including medicine, } \\
\text { dentistry and similar programs) }\end{array}$ & 22 \\
\hline
\end{tabular}

Data on real GDP come from Heston, Summers, and Aten (2009) and is available for 188 countries (including Canada). Relative GDP is measured as the ratio of a tenyear moving average of an immigrant's country of origin real per-capita GDP and that of Canada, for the year the individual immigrated.

In some regressions, we used countries of origin as separate fixed effects. In those instances, we classified the countries as in Grenier and Nadeau (2010) where 48 
countries or groups of countries are selected according to their importance as sources of immigration. 
Table 1

Summary Statistics ${ }^{\dagger}$

\begin{tabular}{|l|r|r|}
\hline & $\begin{array}{c}\text { Canadian } \\
\text { Born } \\
\text { Individuals }\end{array}$ & Immigrants \\
\hline Weekly earnings & 1185.2 & 1057.1 \\
\hline Ln weekly earnings & 6.9 & 6.8 \\
\hline Years of schooling & 13.3 & 14.0 \\
\hline Total potential experience (years) & 21.6 & 25.2 \\
\hline Domestic & 21.6 & 13.7 \\
\hline Foreign & n.a. & 11.5 \\
\hline Real GDP per capita ratio & n.a. & 0.35 \\
\hline Sample size & 585,295 & 57,065 \\
\hline
\end{tabular}

${ }^{\dagger}$ Full-time, full-year working males between 18 and 64. Immigrants are defined as having obtained their highest diploma in their country of origin.

Source: Calculations from Statistics Canada 2006 census data.

Table 2

Returns to Years of Schooling and Years of Work Experience ${ }^{\dagger}$

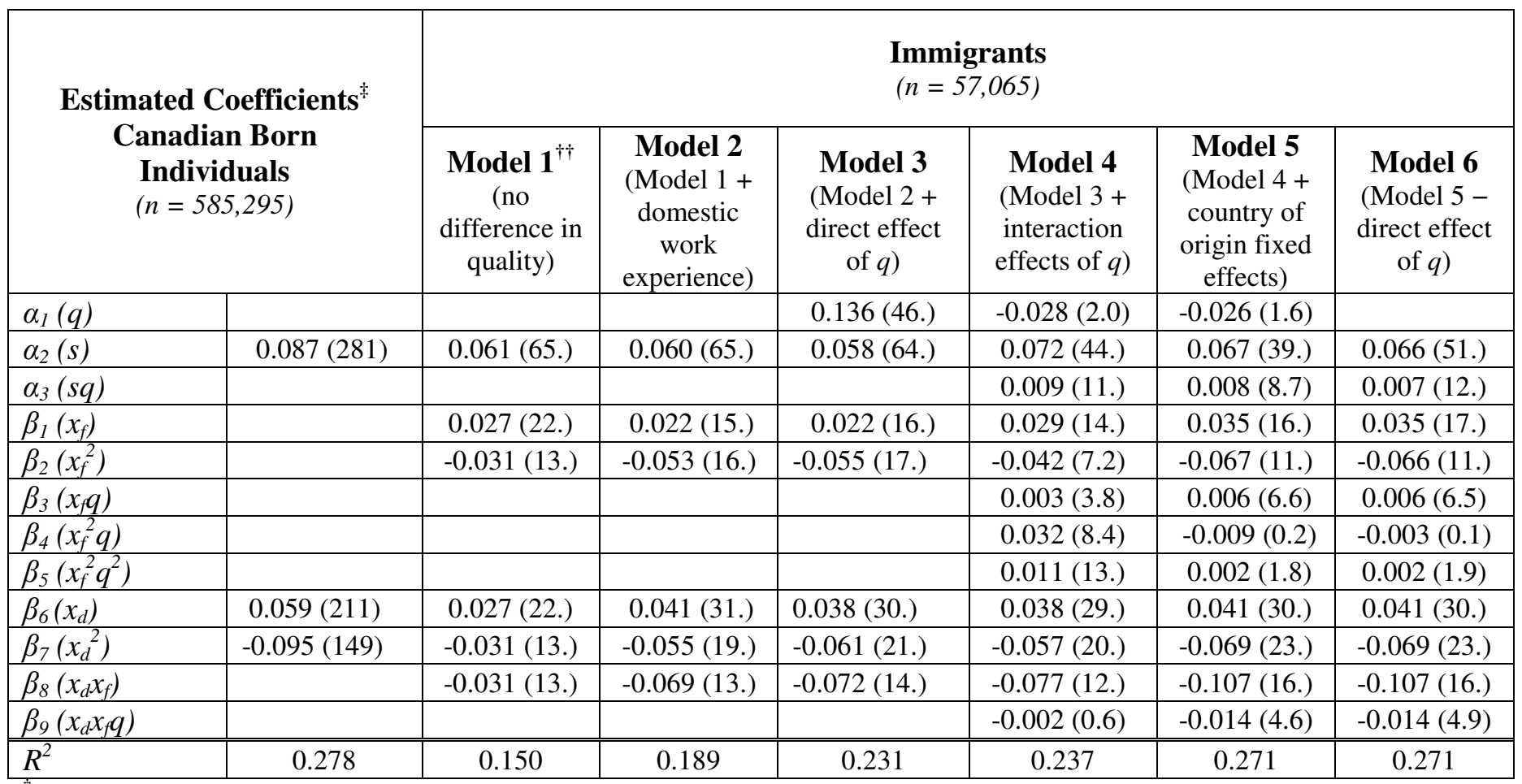

Absolute t-ratio in parentheses. The dependent variable is $\ln$ (weekly earnings). Also included in regressions are five regions of residence indicators, three language spoken indicators and, in Model 5and Model 6, 47 immigrant country of origin dummy variables.

${ }^{*}$ Associated independent variables are between parentheses. The estimated returns to variables in $x^{2}$ have been multiplied by 100 .

${ }^{\dagger}$ In Model 1, the return to foreign work experience is assumed to be the same as the return to domestic work experience. 
Table 3

Impact of Differences in Human Capital Quality on GDP per Capita

\begin{tabular}{|c|c|c|c|c|}
\hline \multirow{3}{*}{$\begin{array}{l}\text { GDP per Capita } \\
\text { (relative to } \\
\text { Canada) }\end{array}$} & \multicolumn{4}{|c|}{$\begin{array}{l}\text { Change in GDP per Capita if same Human } \\
\text { Capital Quality as Canada's (in percent) }\end{array}$} \\
\hline & \multirow{2}{*}{$\begin{array}{c}\text { Years of } \\
\text { Schooling }\end{array}$} & \multicolumn{3}{|c|}{$\begin{array}{c}\text { Potential Years of Work } \\
\text { Experience }\end{array}$} \\
\hline & & 20 & 25 & 30 \\
\hline \multirow{3}{*}{$\begin{array}{c}0.05 \\
\text { (e.g., Uganda) }\end{array}$} & 4 & 37.0 & 441.9 & 45.9 \\
\hline & 8 & 45.4 & 50.3 & 54.3 \\
\hline & 12 & 53.8 & 58.7 & 62.7 \\
\hline \multirow{3}{*}{$\begin{array}{c}0.10 \\
\text { (e.g., India) }\end{array}$} & 4 & 29.6 & 34.1 & 38.0 \\
\hline & 8 & 36.1 & 40.5 & 44.4 \\
\hline & 12 & 42.6 & 47.0 & 50.9 \\
\hline \multirow{3}{*}{$\begin{array}{c}0.50 \\
\text { (e.g., Argentina) }\end{array}$} & 4 & 9.8 & 111.6 & $\begin{array}{l}13.3 \\
\end{array}$ \\
\hline & 8 & 11.7 & 13.5 & 15.3 \\
\hline & 12 & 13.7 & 15.5 & 17.2 \\
\hline \multirow{3}{*}{$\begin{array}{c}1.25 \\
\text { (e.g., U.S.) }\end{array}$} & 4 & -3.3 & -4.0 & -4.6 \\
\hline & 8 & -3.9 & -4.6 & -5.3 \\
\hline & 12 & -4.6 & -5.2 & -5.9 \\
\hline
\end{tabular}

'Figures in the table are natural logarithm percentage points corresponding to $\Delta y(j, k)_{q}$ (see equation (12))estimated using the coefficients of Model 6in Table 2 multiplied by -100 .

Table 4

Impact of Differences in Human Capital Quality on GDP per Capita Ratio

\begin{tabular}{|c|c|c|c|c|}
\hline \multirow{3}{*}{ GDP per Capita Ratio } & \multicolumn{4}{|c|}{$\begin{array}{c}\text { GDP per Capita Ratio if same Human Capital } \\
\text { Quality as Canada's }\end{array}$} \\
\hline & \multirow[t]{2}{*}{$\begin{array}{c}\text { Years of } \\
\text { Schooling }\end{array}$} & \multicolumn{3}{|c|}{$\begin{array}{c}\text { Potential Years of Work } \\
\text { Experience }\end{array}$} \\
\hline & & 20 & 25 & 30 \\
\hline \multirow{3}{*}{$\begin{array}{c}20: 1 \\
(\text { e.g.,Canada:Uganda })\end{array}$} & 4 & 14.6:1 & 14.1:1 & $13.7: 1$ \\
\hline & 8 & $13.8: 1$ & 13.3:1 & 13.0:1 \\
\hline & 12 & $13.0: 1$ & 12.6:1 & $12.3: 1$ \\
\hline \multirow{3}{*}{$\begin{array}{c}\text { 10:1 } \\
\text { (e.g.,Canada:India) }\end{array}$} & 4 & $7.71: 1$ & $7.46: 1$ & $7.25: 1$ \\
\hline & 8 & $7.35: 1$ & $7.12: 1$ & 6.92:1 \\
\hline & 12 & $7.01: 1$ & $6.80: 1$ & $6.63: 1$ \\
\hline \multirow{3}{*}{$\begin{array}{c}2: 1 \\
\text { (e.g., Canada: } \\
\text { Argentina) }\end{array}$} & 4 & $1.82: 1$ & 1.79:1 & $1.76: 1$ \\
\hline & 8 & $1.79: 1$ & $1.76: 1$ & $1.73: 1$ \\
\hline & 12 & $1.76: 1$ & 1.73:1 & $1.71: 1$ \\
\hline \multirow{3}{*}{$\begin{array}{c}0.8: 1 \\
\text { (e.g.,Canada:U.S.) }\end{array}$} & 4 & $0.83: 1$ & $0.83: 1$ & $0.84: 1$ \\
\hline & 8 & $0.83: 1$ & $0.84: 1$ & $0.84: 1$ \\
\hline & 12 & $0.84: 1$ & $0.84: 1$ & $0.85: 1$ \\
\hline
\end{tabular}

Figures in the table are calculated as GDP per Capita Ratio divided by $\left(1+\Delta y(j, k)_{q}\right)$ where $\Delta y(j, k)_{q}$ is defined by equation (12) and estimated using the coefficients of Model 6 in Table 2. 
Table 5

Decomposition of the Impact of Differences in Human Capital Quality on GDP per Capita ${ }^{\dagger}$

(Selected Years of schooling -Years of work experience combinations)

\begin{tabular}{|c|c|c|c|c|}
\hline \multirow{2}{*}{$\begin{array}{c}\text { GDP per Capita } \\
\text { (relative to } \\
\text { Canada) }\end{array}$} & \multirow{2}{*}{ Quality Effects } & \multicolumn{3}{|c|}{$(\mathbf{s}, \mathbf{x})$ Combinations } \\
\hline & & $(4,30)$ & $(8,25)$ & $(12,20)$ \\
\hline \multirow{3}{*}{$\begin{array}{c}0.05 \\
\text { (e.g., Uganda) }\end{array}$} & Schooling & 8.4 & 16.8 & 25.2 \\
\hline & Potential Work Experience & 37.5 & 33.5 & 28.6 \\
\hline & Total & 45.9 & 50.3 & 53.8 \\
\hline \multirow{3}{*}{$\begin{array}{c}0.10 \\
\text { (e.g., India) }\end{array}$} & Schooling & 6.5 & 12.9 & 19.4 \\
\hline & Potential Work Experience & 31.5 & 27.6 & 23.2 \\
\hline & Total & 38.0 & 40.5 & 42.6 \\
\hline \multirow{3}{*}{$\begin{array}{c}0.50 \\
\text { (e.g., Argentina) }\end{array}$} & Schooling & 1.9 & 3.9 & 5.8 \\
\hline & Potential Work Experience & 11.4 & 9.6 & 7.8 \\
\hline & Total & 13.3 & 13.5 & 13.7 \\
\hline \multirow{3}{*}{$\begin{array}{c}1.25 \\
\text { (e.g., U.S.) }\end{array}$} & Schooling & -0.6 & -1.3 & -1.9 \\
\hline & Potential Work Experience & -4.0 & -3.3 & -2.7 \\
\hline & Total & -4.6 & -4.6 & -4.6 \\
\hline
\end{tabular}

"Figures in the table are natural logarithm percentage points. The decomposition is based on equations $(12 b)$ and (12c) in the text.

Table 6

Decomposition of the Impact of Differences in Human Capital Quality on GDP per Capita (Normalized for one year of schooling and one year of work experience) ${ }^{\dagger}$

\begin{tabular}{|l|c|c|c|c|}
\hline \multirow{2}{*}{\multicolumn{1}{|c|}{ Quality Effects }} & \multicolumn{3}{|c|}{ GDP per Capita (relative to Canada) } \\
\cline { 2 - 5 } & $\begin{array}{c}\mathbf{0 . 0 5} \\
\text { (e.g., Uganda) }\end{array}$ & $\begin{array}{c}\mathbf{0 . 1 0} \\
\text { (e.g., India) }\end{array}$ & $\begin{array}{c}\mathbf{0 . 5 0} \\
\text { (e.g., Argentina) }\end{array}$ & $\begin{array}{c}\mathbf{1 . 2 5} \\
\text { (e.g., U.S.) }\end{array}$ \\
\hline One year of schooling & 2.10 & 1.62 & 0.49 & 0.16 \\
\hline $\begin{array}{l}\text { One year of potential work } \\
\text { experience }\end{array}$ & 1.77 & 1.36 & 0.41 & 0.13 \\
\hline
\end{tabular}

Figures in the table are natural logarithm percentage points and are measured as the quality effects of an additional year of schooling and an additional year of work-experience (evaluated at $x=20$ ). 